\title{
PERANCANGAN DINDING PENAHAN TANAH PADA (KONSTRUKSI) BASEMENT DENGAN DUKUNGAN STRUT-BEAM
}

\author{
Renaldo Livando ${ }^{1}$ dan Aksan Kawanda ${ }^{2}$ \\ ${ }^{1}$ Program Studi Sarjana Teknik Sipil, Universitas Tarumanagara, Jl. Letjen S. Parman No.1 Jakarta \\ Renaldolivando6@gmail.com \\ ${ }^{2}$ Program Studi Doktor Teknik Sipil, Universitas Katolik Parahyangan, Jl. Ciumbuleuit No.94, Jawa Barat \\ aksank@dtt.untar.ac.id
}

Masuk: 08-07-2020, revisi: 22-07-2020, diterima untuk diterbitkan: 05-08-2020

\begin{abstract}
Basement development in the construction world has become common. The contractor is expected to be able to master the knowledge for the construction of the basement. In practice, it cannot use only one or two methods to be used in each field condition. Many things must be estimated to design a structure, in addition to choosing the shape of the retaining wall used, the selection of support becomes something that must really be considered by looking at field conditions. An example that must be considered in designing a retaining wall itself is the stress of the soil that must be calculated appropriately so as not to damage the retaining wall itself. In addition, the relationship used between projects with deep or shallow excavations. If the retaining wall is lacking or not strong enough to withstand the stresses of the soil, it must be assisted with a support system that will withstand some of the lateral pressure exerted by the soil. In this analysis, the focus of the discussion is on the support system strutting model or can be called a strut-beam that is used to support the diaphgarm wall.
\end{abstract}

Keywords: basement; retaining wall; deep excavation; strut

\begin{abstract}
ABSTRAK
Pembangunan basement dalam dunia konstruksi sudah menjadi sesuatu yang umum. Kontraktor diharapkan sudah dapat dapat menguasai ilmu untuk pembangunan basement. Dalam prakteknya, tidak bisa menggunakan hanya satu atau dua metode untuk dipakai dalam setiap kondisi lapangan. Banyak hal yang harus diperkirakan untuk medesign sebuah struktur, selain pemilihan bentuk dinding penahan tanah yang digunakan, pemilihan support pun menjadi hal yang harus benar-benar dipertimbangkan dengan melihat kondisi lapangan. Contoh yang harus dipertimbangkan dalam mendesign dinding penahan tanah sendiri adalah tegangan tanah yang harus diperhitungkan secara tepat agar tidak merusak dinding penahan tanah itu sendiri. Selain itu juga perhtiungan yang digunakan antara proyek dengan galian dalam atau galian dangkal. Jika dinding penahan tanah tersebut kurang atau tidak kuat dalam menahan tegangan tanah maka harus dibantu dengan support system yang akan menahan sebagian tekanan lateral yang diberikan oleh tanah. Dalam analisis ini, fokus pembahasan ada pada support system model strutting atau bisa disebut strut-beam yang digunakan untuk mendukung diaphgarm wall.
\end{abstract}

Kata kunci: basement; dinding penahan tanah; galian dalam; strut

\section{PENDAHULUAN}

Meluasnya struktur perkotaan dan pertambahan penduduk yang cepat menimbulkan tantangan untuk mencari ruang yang dapat digunakan di kota-kota besar. Para pengembang semakin terorientasi untuk membangun bangunan dengan struktur yang semakin tinggi walaupun dengan lahan yang tergolong sempit, dan karena adanya kebutuhan lahan parkir, bangunan juga harus membutuhkan basement sehingga struktur bangunan semakin lama semakin dalam. Seringnya bangunan-bangunan yang ada di daerah dengan ketersediaan lahan sempit memiliki dua sampai tiga basement ataupun lebih. 
Untuk pembangunan yang membutuhkan galian sudah hampir tidak mungkin untuk memanfaatkan kemiringan lereng sebagai penahan tanah. Maka dari itu dibutuhkan dukungan galian yang dapat berbentuk diaphragm wall ataupun sheet pile. Namun untuk galian dalam, struktur tersebut sangat mungkin untuk membutuhkan dukungan tambahan, metode yang dapat digunakan untuk mengatasi masalah ini salah satunya adalah dengan galian bertahap dan memberikan dukungan tambahan, seperti pengunaan struts, ground anchor, dan juga campuran sistem strutting/anchoring.

Pemilihan sistem yang digunakan harus didasarkan dari keadaan di lapangan. Pada kasus proyek dengan lahan yang sempit dan adanya pertimbangan pengaruh terhadap bangunan/proyek disebelahnya, strutting merupakan dukungan yang cocok.

\section{Basement}

Basement merupakan lantai tambahan pada bagian paling bawah sebuah gedung, terletak di bawah permukaan tanah dari desain bangunan gedung yang tergolong bangunan tinggi yang tidak mempunyai lahan kosong yang cukup baik di sekitar gedung ataupun untuk memberi lantai tambahan lagi di atas gedung. ada tiga hal penting yang perlu diperhatikan, yaitu metode konstruksi, retaining wall dan dewatering.

\section{Dinding penahan tanah}

Dinding penahan tanah adalah sebuah struktur pada bidang geoteknik yang memiliki fungsi untuk memberikan tahanan terhadap tekanan tanah lateral akibat dari pengembangan atau keruntuhan tanah itu. Struktur dapat terguling atau akan tergeser karena adanya dorongan aktif yang diberikan oleh tanah yang tertahan. Dinding penahan tanah juga digunakan untuk membantu proses penggalian. Dinding tersebut sering diaplikasikan pada banyak proyek seperti jalan raya, irigasi, dan struktur-struktur fondasi seperti bangunan ruang bawah tanah karena kemampuannya untuk menahan tekanan tanah.

\section{Tegangan tanah lateral}

Teganan tanah lateral merupakan gaya yang dihasilkan karena adanyaa dorongan atau tekanan dengan arah horizontal atau lateral dari tanah ke struktur penahan tanah. Maka dari itu struktur yang menerima gaya horizontal/lateral ini harus dipertimbangkan desainnya sedemikian rupa agar sesuai dengan ketentuan yang ada sehingga struktur tidak mengalami kegagalan. Tegangan tanah lateral dipengaruhi berbagai faktor, sebagai berikut: Nilai kohesi pada tanah, nilai koefisien tegangan lateral dalam keadaan diam (Ko), aktif (Ka), dan pasif (Kp), dan yang mempengaruhi struktur.

\section{Koefisien tanah lateral dalam keadaan diam}

Koefisien tanah lateral saat tanah dalam keadaan diam adalah tekanan tanah yang terjadi akibat massa tanah pada dinding penahan dalam keadaan seimbang. Pada Gambar 1 terlihat suatu massa tanah yang ditahan oleh struktur penahan tanah $\mathrm{AB}$ dengan tinggi $\mathrm{H}$. Dinding penahan $\mathrm{AB}$ berada dalam keadaan diam, sedangkan untuk massa tanah dalam keadaan keseimbangan elastic.

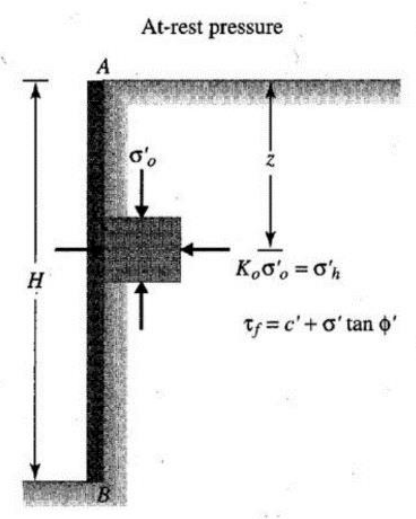

Gambar 1. Tekanan tanah lateral dalam keadaan diam

(Sumber: Das, 2002) 
Menurut Jaky (1944) dalam Hardyatmo (1996) koefisien tekanan tanah lateral dalam keadaan diam dapat dituliskan berdasarkan hubungan empiris sebagai berikut:

$$
K_{0}=1-\operatorname{Sin} \varphi
$$

dengan $K_{0}=$ koefisien tanah lateral dalam keadaan diam.

\section{Koefisien tanah lateral aktif}

Koefisien tanah lateral saat dorongan yang diberikan tanah searah dengan pergerakan tanah. Massa tanah telah berada dalam kondisi plastic equilibrium. Pada Gambar 2 menunjukan bahwa tegangan tanah lateral memberikan gaya yang lebih besar dibanding gaya dinding penahan tanah yang menahannya sehingga mendorong ke arah dinding penahan tanah.

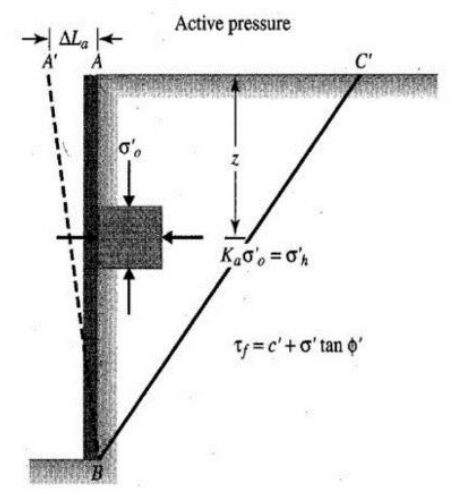

Gambar 2. Tekanan tanah lateral aktif

(Sumber: Das, 2002)

\section{Koefisien tanah lateral pasif}

Koefisien tanah lateral saat dorongan yang diberikan tanah berlawanan dengan pergerakan tanah. Massa tanah telah berada dalam kondisi plastic equilibrium. Pada Gambar 3 menunjukan bahwa tegangan tanah lateral memberikan gaya yang lebih kecil dibanding gaya dinding penahan tanah yang menahannya sehingga mendorong ke arah tanah.

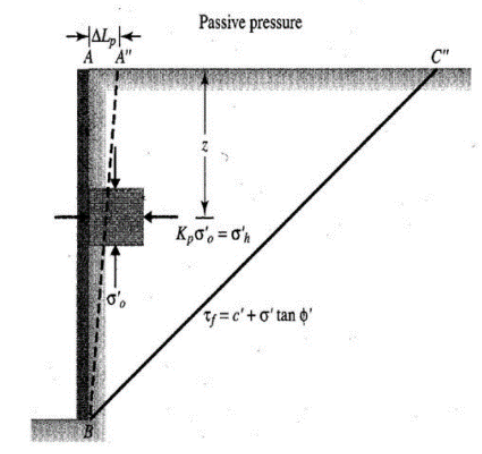

Gambar 3. Tekanan tanah lateral pasif

(Sumber: Das, 2002)

\section{Teori Rankine (1857)}

Berdasarkan Teori dari Rankine dalam Hardyatmo (1996) koefisien tekanan tanah aktif dan pasif pada permukaan tanah datar ditulis dengan persamaan sebagai berikut: 


$$
\begin{gathered}
K_{a}=\tan ^{2}\left(45-\frac{\theta^{\prime}}{2}\right) \\
K_{p}=\tan ^{2}\left(45+\frac{\theta^{\prime}}{2}\right) \\
\sigma_{h a}^{\prime}=\sigma_{v}^{\prime} \cdot K_{a}-2 c^{\prime} \sqrt{K_{a}} \\
\sigma_{h p}^{\prime}=\sigma_{v}^{\prime} \cdot K_{p}+2 c^{\prime} \sqrt{K_{p}}
\end{gathered}
$$

dengan $K_{a}=$ koefisien tekanan tanah aktif, $K_{p}=$ koefisien tekanan tanah pasif, $c^{\prime}=$ kohesi, $\theta^{\prime}=$ sudut geser dalam tanah, $\sigma_{h a}^{\prime}=$ tegangan tanah lateral aktif, $\sigma_{h p}^{\prime}=$ tegangan tanah lateral pasif, $\sigma_{v}^{\prime}{ }_{v}=$ tegangan vertikal efektif.

\section{Teori Coulomb (1776)}

Berdasarkan Teori dari Coulomb dalam Hardyatmo (1996) koefisien tekanan tanah aktif dan pasif pada permukaan tanah datar ditulis dengan persamaan sebagai berikut:

$$
\begin{gathered}
K_{a}=\frac{\sin ^{2}\left(\beta+\theta^{\prime}\right)}{\sin ^{2} \beta \cdot \sin (\beta-\delta)\left[1+\sqrt{\frac{\sin \left(\theta^{\prime}+\delta\right) \cdot \sin \left(\theta^{\prime}-\alpha\right)}{\sin (\beta-\delta) \cdot \sin (\alpha+\beta)}}\right]^{2}} \\
K_{p}=\frac{\sin ^{2}\left(c-\theta^{\prime}\right)}{\sin ^{2} \beta \cdot \sin (\beta+\delta)\left[1-\sqrt{\frac{\sin \left(\theta^{\prime}+\delta\right) \cdot \sin \left(\theta^{\prime}+\alpha\right)}{\sin (\beta+\delta) \cdot \sin (\alpha+\beta)}}\right]^{2}} \\
\sigma_{h a}^{\prime}=\sigma_{v}^{\prime} \cdot K_{a}-2 c^{\prime} \sqrt{K_{a}} \\
\sigma_{h p}^{\prime}=\sigma_{v}^{\prime} \cdot K_{p}+2 c^{\prime} \sqrt{K_{p}}
\end{gathered}
$$

dengan $K_{a}=$ koefisien tekanan tanah aktif, $K_{p}=$ koefisien tekanan tanah pasif, $\theta^{\prime}=$ sudut geser dalam tanah, $c^{\prime}=$ kohesi, $\alpha=$ sudut kemiringan backfill, $\beta=$ sudut kemiringan dinding penahan, $\delta=$ sudut kemiringan tegak lurus tegangan.

\section{Sistem strutting}

Sistem strutting dipasang ketika diperlukan dukungan tambahan untuk mengontrol pergerakan atau defleksi dinding. Sistem ini terdiri dari lapisan waler dan struts yang biasa terbuat dari balok baja.

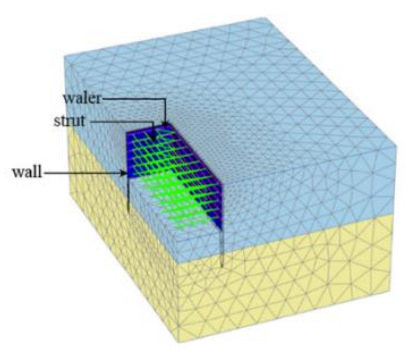

Gambar 4. Galian 3D dengan sistem strutting

(Sumber: Wengang Zhang, 2019)

\section{Strut}


Setiap strut dalam penahan galian sebaiknya dibuat proporsional terhadap beban maksimum yang diberikan oleh diagram tekanan. Prosedur sederhana diberikan pada Gambar 4. Untuk mengurani pergerakan sistem penahan tanah, strut biasanya diprestress pada waktu pemasangan antara 40\% sampai dengan $70 \%$ terhadap beban maksimum yang mungkin terjadi. Wales

Wales umumnya terbuat dari baja H. Lendutan dari wales dan $D$-wall di antara strut menyebabkan tekanan geser pada tanah, hal ini akan mentransfer sebagian beban langsung kebagian penahan yang kaku. Karena itu wales, $D$ wall tidak perlu direncanakan untuk menahan bending momen maksimum.

\section{Tegangan pada desain galian dalam}

Pada tanah seragam Peck (1969) dalam Das (2002) menyatakan tegangan lateral untuk jenis tanah pasir dapat di ilustrasikan pada Gambar 5 dan dinyatakan dengan rumus:

$$
\sigma_{a}=0.65 \gamma H K_{a}
$$

dengan $\gamma=$ berat jenis $\left(\mathrm{kN} / \mathrm{m}^{3}\right), \mathrm{H}=$ tinggi potongan $(\mathrm{m}), K_{a}=$ koefisien tanah lateral aktif.

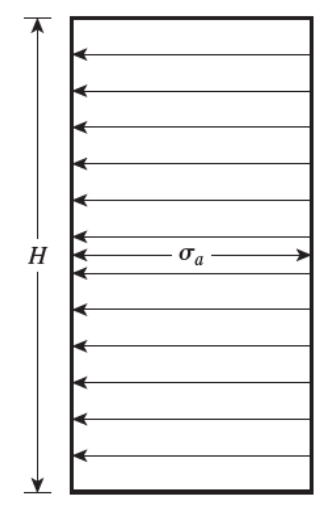

Gambar 5. Tegangan tanah lateral pada pasir

(Sumber: Das, 2002)

Sedangkan tegangan lateral untuk jenis tanah lempung lunak sampai sedang untuk kondisi $\frac{\gamma H}{c}>4$, teganan lateral dapat diilustrasikan pada Gambar 6 dinyatakan dengan rumus:

$$
\sigma_{a}=\gamma H\left[1-\left(\frac{4 c}{\gamma H}\right)\right]
$$

dengan $c=\operatorname{kohesi}\left(\mathrm{kN} / \mathrm{m}^{2}\right), \gamma=$ berat jenis $\left(\mathrm{kN} / \mathrm{m}^{3}\right), \mathrm{H}=\operatorname{tinggi}$ potongan $(\mathrm{m})$.

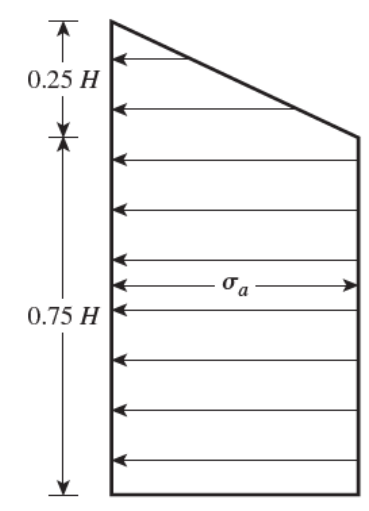

Gambar 6. Tegangan tanah lateral pada tanah lempung lunak sampai sedang 
(Sumber: Das, 2002)

Dan tegangan tanah lateral untuk jenis tanah lempung keras dengan kondisi $\frac{\gamma H}{c} \leq 4$, teganan lateral dapat diilustrasikan pada Gambar 7 dinyatakan dengan rumus:

$$
\sigma_{a}=0.2 \gamma H \text { sampai } 0.4 \gamma H
$$

dengan $\gamma=$ berat jenis $\left(\mathrm{kN} / \mathrm{m}^{3}\right), \mathrm{H}=$ tinggi potongan $(\mathrm{m})$.

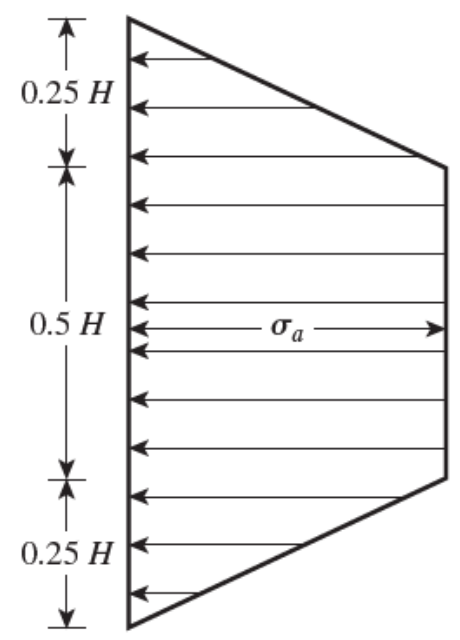

Gambar 7. Tegangan tanah lateral pada tanah lempung keras

(Sumber: Das, 2002)

Seringkali lapisan pada tanah merupakan lapisan yang memiliki beberapa jenis tanah dari pasir hingga lempung, terutama untuk galian dalam. Peck (1943) dalam Das (2002) merumuskan pencarian nilai kohesi rata-rata dapat dirumuskan:

$$
c_{a v}=\frac{1}{2 H}\left[\gamma_{s} K_{s} H_{s}^{2} \tan \phi_{s}+\left(H-H_{s}\right) n^{\prime} q_{u}\right.
$$

dengan $H=$ tinggi total potongan $(\mathrm{m}), \gamma_{s}=$ berat jenis pasir $\left(\mathrm{kN} / \mathrm{m}^{3}\right), H_{s}=$ tinggi lapisan pasir $(\mathrm{m}), K_{s}=$ koefisien tanah lateral pada pasir, $\phi_{s}=$ sudut geser pasir $\left({ }^{\circ}\right), q_{u}=$ kuat tekan undrained lempung $\left(\mathrm{kN} / \mathrm{m}^{2}\right), n^{\prime}=$ koefisien failure (0.5 sampai 1$)$.

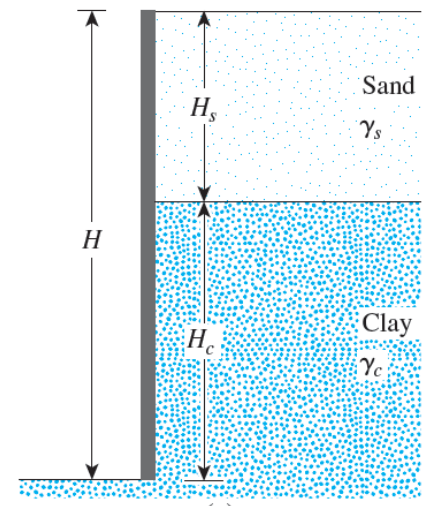

(a)

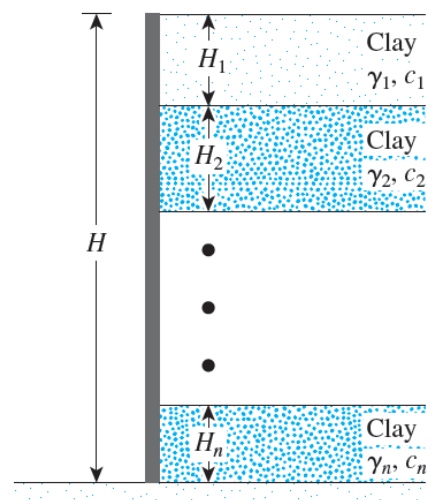

(b)

Gambar 8. Lapisan tanah beragam pada braced-cut 
(Sumber: Das, 2002)

Berdasarkan Gambar 8a berat jenis rata-rata pada lapisan tanah beragam dapat dirumuskan sebagai berikut:

$$
\gamma_{a}=\frac{1}{H}\left[\gamma_{s} H_{s}+\left(H-H_{s}\right) \gamma_{c}\right.
$$

dengan $\gamma_{c}=$ berat jenis dari lapisan lempung.

Jika ada beberapa lapisan seperti Gambar 8b, nilai kohesi rata-rata dapat dirumuskan sebagai berikut:

$$
c_{a v}=\frac{1}{H}\left(c_{1} H_{1}+c_{2} H_{2}+\cdots+c_{n} H_{n}\right)
$$

Dengan $c_{1}, c_{2}, \ldots, c_{n}=$ nilai kohesi pada lapisan $1,2, \ldots, \mathrm{n}, H_{1}, H_{2}, \ldots, H_{n}=$ tebal lapisan $1,2, \ldots, \mathrm{n}$.

Maka dapat dihitung berat jenis rata-rata

$$
\gamma_{a v}=\frac{1}{H}\left(\gamma_{1} H_{1}+\gamma_{2} H_{2}+\cdots+\gamma_{n} H_{n}\right)
$$

\section{Stabilitas bottom heave}

Braced-cut pada tanah dapat membuat bagian dasar tanah menjadi tidak stabil. Terzaghi (1943) dalam Braja (2002) menganalisa factor keamanan untuk braced-cut pada galian dalam, dirumuskan:

$$
F S=\frac{5.14 c_{a v}\left(1+\frac{0,2 B^{\prime \prime}}{L}\right)+\frac{c_{a v} H}{B^{\prime}}}{\gamma_{a} H+q}
$$

Dengan ketentuan $B^{\prime}=T$ jika $T \leq B / \sqrt{2} ; B^{\prime}=B / \sqrt{2} j i k a T>B / \sqrt{2} ; B^{\prime \prime}=\sqrt{2} B^{\prime}$

dengan $\mathrm{FS}=$ faktor keamanan base heave, $\mathrm{T}=$ tinggi lapsain base heave $(\mathrm{m}), c_{a v}=$ kohesi undrained rata-rata, $\gamma=$ berat jenis tanah, $\mathrm{q}=$ beban luar.

\section{METODE PENELITIAN}

\section{Wilayah penelitian}

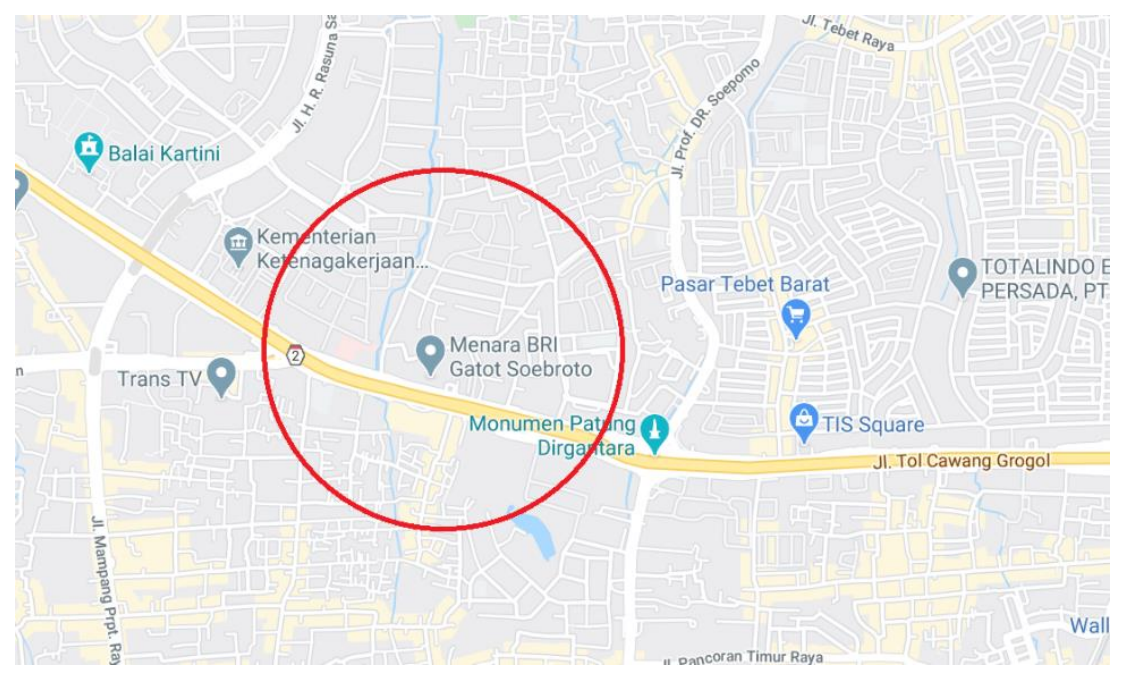

Gambar 9. Wilayah penelitian

\section{Data yang digunakan}

Teknik pengumpulan data pada penelitian ini hanya menggunakan data sekunder yang diperoleh dari instansiinstansi terkait penelitian ini. Adapaun data sekunder yang digunakan sebagai berikut:

1. Data shop drawing

2. Data sondir 

3. Data borlog
4. Data laboratorium

\section{Analisis Data}

1. Memperhitungkan dan memodelkan tegangan tiap lapisan tanah

2. Memperhitungkan dan memodelkan tegangan lapisan tanah rata-rata

3. Menghitung beban resultan pada masing-masing strut dan wales

4. Melakukan pengecekan terhadap stabilitas bottom heave

\section{HASIL DAN PEMBAHASAN.}

\section{Perhitungan tegangan aktif pasif tiap lapisan galian dalam}

Perhitungan tegangan aktif pasif tiap lapisan disini berdasarkan dengan teori Peck (1969) tentang tegangan lateral untuk jenis tanah seragam. Mayoritas lapisan tanah merupakan lapisan tanah lempung keras sehingga diagram tegangan berbentuk trapesium sama kaki namun pada tanah pasif lapisan 30-36,5m terdapat lapisan pasir sehingga menghasilkan diagram teganan persegi.

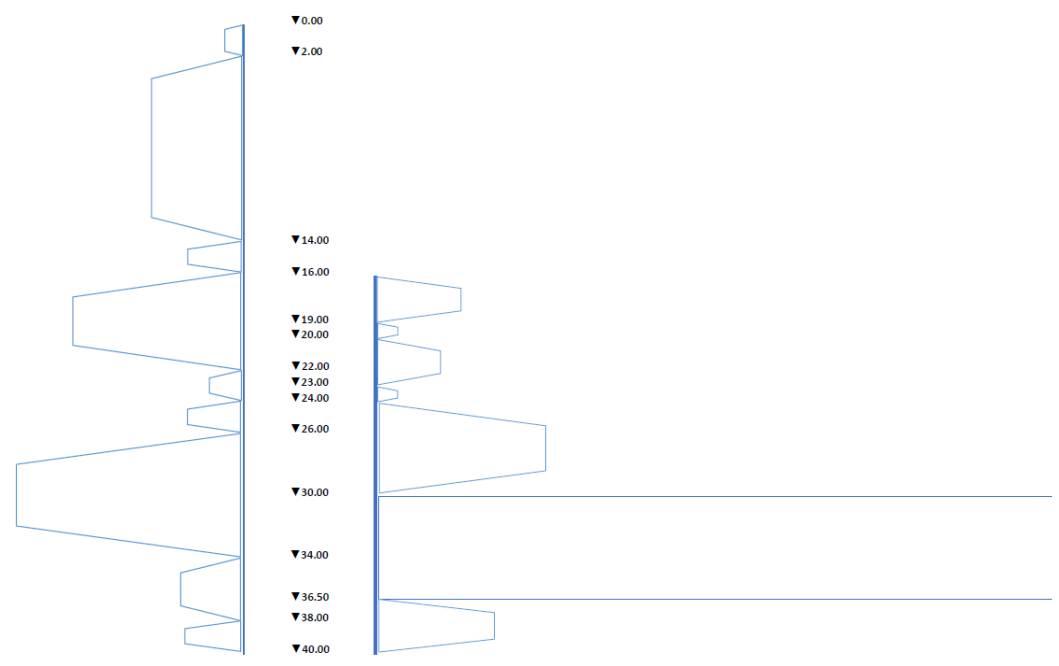

Gambar 10. Diagram tegangan tiap lapisan galian dalam

\section{Perhitungan tegangan aktif pasif rata-rata galian dalam}

Perhitungan tegangan aktif pasif tiap lapisan disini berdasarkan dengan teori Peck (1969) dalam Braja (2002) tentang tegangan lateral untuk jenis tanah non-seragam. Mayoritas data pada Tabel 1 dan Tabel 2 didapat dengan menggunakan korelasi namun ada sedikit data yang didapat dari data hasil laboratorium.

Tabel 1. Data kohesi dan berat jenis rata-rata untuk tanah aktif

\begin{tabular}{ccccccc}
\hline Depth $(\mathrm{m})$ & High $(\mathrm{m})$ & $\mathrm{N}-\mathrm{SPT}$ & $\mathrm{c}\left(\mathrm{kN} / \mathrm{m}^{2}\right)$ & $\gamma\left(\mathrm{kN} / \mathrm{m}^{3}\right)$ & $\gamma \mathrm{H}(\mathrm{kN} / \mathrm{m})$ & $\mathrm{cH}(\mathrm{kN} / \mathrm{m})$ \\
\hline 0 & 2 & 6 & 3,60 & 7,00 & 14 & 7,2 \\
\hline 2 & 12 & 15 & 22,00 & 4,00 & 48 & 264 \\
\hline 14 & 2 & 40 & 24,00 & 10,70 & 21,4 & 48 \\
\hline 16 & 6 & 50 & 30,00 & 11,20 & 67,2 & 180 \\
\hline 22 & 2 & 23 & 13,80 & 8,50 & 17 & 27,6 \\
\hline 24 & 2 & 39 & 23,40 & 10,65 & 21,3 & 46,8 \\
\hline 26 & 8 & 50 & 30,00 & 11,20 & 89,6 & 240 \\
\hline 34 & 4 & 24 & 14,40 & 8,00 & 32 & 57,6 \\
\hline 38 & 2 & 50 & 30,00 & 11,20 & 22,4 & 60 \\
\hline 40 & & & & & 332,9 & 931,2 \\
\hline Total & 40 & &
\end{tabular}


Keterangan: High merupakan selisih dari kolom Depth

Nilai kohesi rata-rata:

$c_{\text {ava }}=\frac{1}{H}(\Sigma c H)=\frac{1}{40}(931,2)=23,28 \mathrm{kN} / \mathrm{m}^{2}$

Nilai berat jenis rata-rata:

$\gamma_{a v a}=\frac{1}{H}(\Sigma \gamma H)=\frac{1}{40}(332,9)=8,3325 \mathrm{kN} / \mathrm{m}^{2}$

$\frac{\gamma_{a v a \times H}}{c_{\text {ava }}}=\frac{8,3325 \times 40}{23,28}=14,29983$

Karena, $\frac{\gamma_{\text {ava } \times H}}{c_{\text {ava }}}>4$

Maka, $\sigma_{a v a}=\gamma_{a v a} H\left[1-\left(\frac{4 c_{a v a}}{\gamma_{a v a} H}\right)\right]=8,3325 \times 40\left[1-\left(\frac{4 \times 23,28}{8,3325 \times 40}\right)\right]=239,78 \mathrm{kN} / \mathrm{m}^{2}$

Tabel 2. Data kohesi dan berat jenis rata-rata untuk tanah pasif

\begin{tabular}{ccccccc}
\hline Depth $(\mathrm{m})$ & High $(\mathrm{m})$ & $\mathrm{N}-\mathrm{SPT}$ & $\mathrm{c}\left(\mathrm{kN} / \mathrm{m}^{2}\right)$ & $\gamma\left(\mathrm{kN} / \mathrm{m}^{3}\right)$ & $\gamma \mathrm{H}(\mathrm{kN} / \mathrm{m})$ & $\mathrm{cH}(\mathrm{kN} / \mathrm{m})$ \\
\hline 16 & 3 & 50 & 30,00 & 11,20 & 33,6 & 90 \\
\hline 19 & 1 & 39 & 23,40 & 10,65 & 10,65 & 23,4 \\
\hline 20 & 3 & 24 & 14,40 & 6,90 & 20,7 & 43,2 \\
\hline 23 & 1 & 36 & 21,60 & 10,50 & 10,5 & 21,6 \\
\hline 24 & 6 & 48 & 28,80 & 11,10 & 66,6 & 172,8 \\
\hline 30 & 6,5 & 50 & 0,00 & 13,20 & 85,8 & - \\
\hline 36,5 & 3,5 & 50 & 30,00 & 13,20 & 46,2 & 105 \\
\hline 40 & & & & & & \\
\hline Total & 24 & & & & & \\
\hline
\end{tabular}

Keterangan: High merupakan selisih dari kolom Depth

Nilai kohesi rata-rata:

$c_{a v p}=\frac{1}{H}(\Sigma c H)=\frac{1}{40}(456)=19 \mathrm{kN} / \mathrm{m}^{2}$

Nilai berat jenis rata-rata:

$\gamma_{a v p}=\frac{1}{H}(\Sigma \gamma H)=\frac{1}{40}(274,05)=11,4188 \mathrm{kN} / \mathrm{m}^{2}$

$\frac{\gamma_{a v p \times H}}{c_{a v p}}=\frac{11,4188 \times 24}{19}=14,4237$

Karena, $\frac{\gamma_{a v p \times H}}{c_{a v p}}>4$

Maka, $\sigma_{a v p}=\gamma_{a v p} H\left[1-\left(\frac{4 c_{a v p}}{\gamma_{a v p} H}\right)\right]=11,4188 \times 24\left[1-\left(\frac{4 \times 19}{11,4188 \times 24}\right)\right]=198,05 \mathrm{kN} / \mathrm{m}^{2}$ 


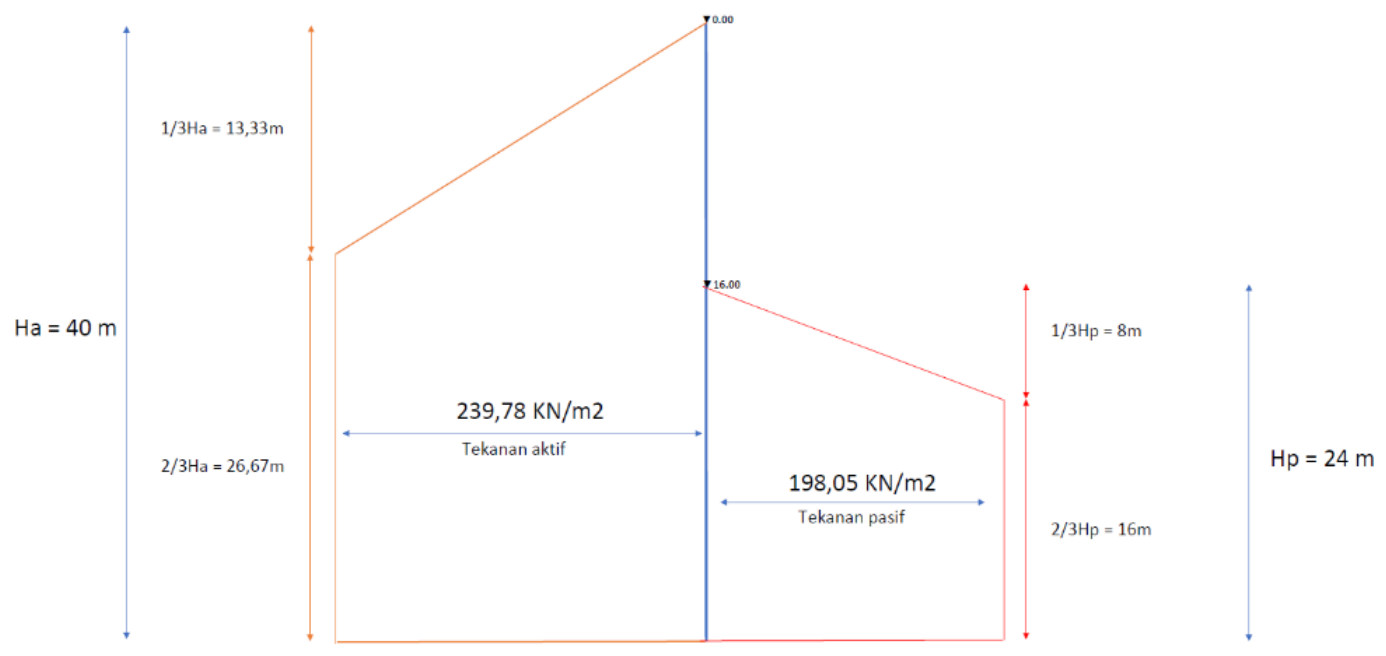

Gambar 11. Diagram tegangan aktif pasif rata-rata

\section{Perhitungan resultan gaya tiap strut dan wales}

Analisa perhitungan analisis ini didasari oleh metode slope deflection. Penelitian ini mencari resultan gaya yang dihasilkan pada tiap strut dan wales akibat tegangan lateral tanah rata-rata.

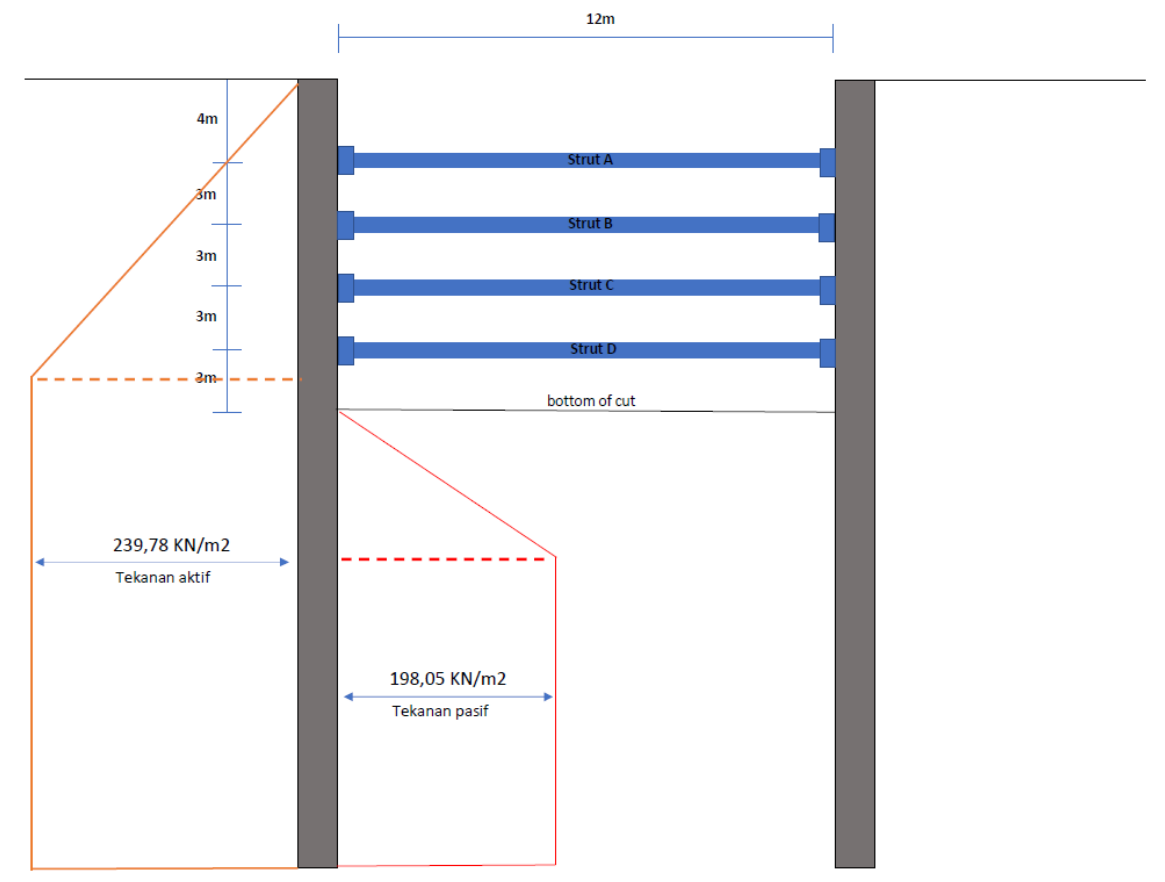

Gambar 12. Sketsa tegangan pada D-wall dan strut-beam 


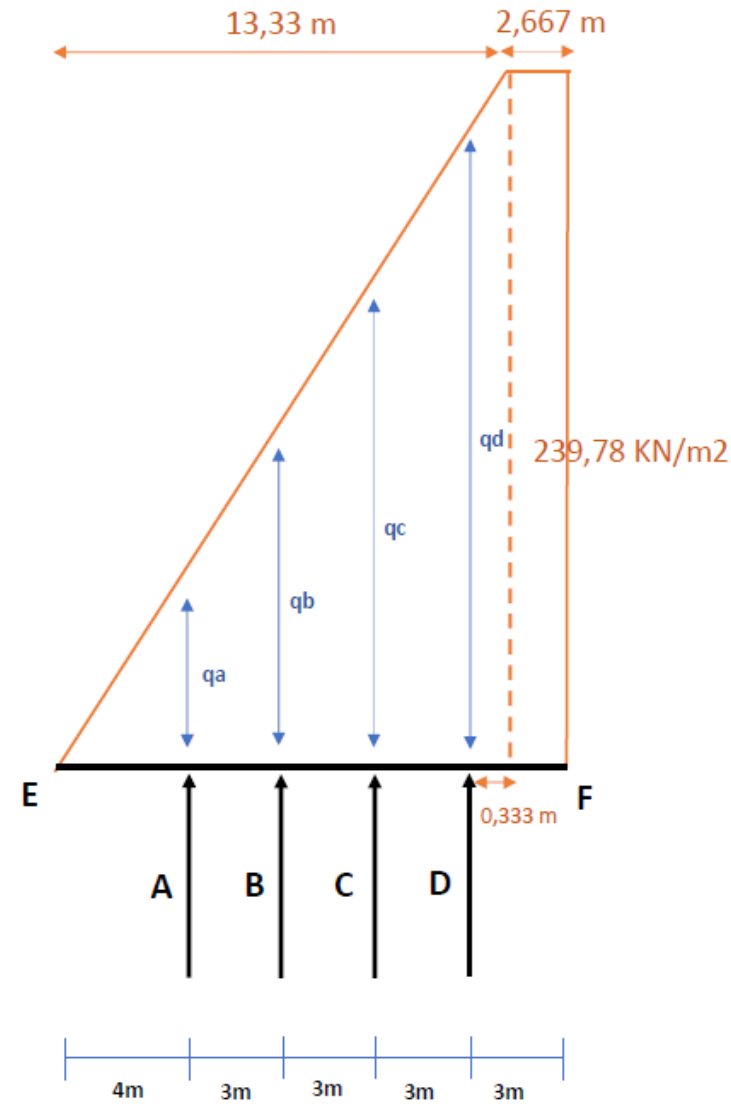

Gambar 13. Perletakan pada strut-beam

Mencari besar qa,qb,qc,qd

$$
\begin{aligned}
\mathrm{qa} & =\frac{293,78 \times 4}{13,333}=71,934 \mathrm{kN} / \mathrm{m}^{2} \\
\mathrm{qb} & =\frac{293,78 \times 7}{13,333}=125,8876 \mathrm{kN} / \mathrm{m}^{2} \\
\mathrm{qc} & =\frac{293,78 \times 10}{13,333}=179,8394 \mathrm{kN} / \mathrm{m}^{2} \\
\mathrm{qd} & =\frac{293,78 \times 13}{13,333}=233,786 \mathrm{kN} / \mathrm{m}^{2}
\end{aligned}
$$

Beban pada bentang EA dan DF disuperposisi menjadi

$$
\begin{aligned}
\text { Beban EA }= & \frac{1}{2} \times 4 \times 71,934 \times\left(\frac{1}{3} \times 4\right)=191,824 \mathrm{kNm} / \text { meter of wall } \\
\text { Beban DF }= & \frac{1}{2} \times 0,333 \times(293,78-233,786) \times\left(\frac{2}{3} \times 0,333\right)+233,786 \times 0.333 \times\left(\frac{1}{2} \times 0.33\right) \\
& +239,78 \times 2,667 \times\left(\frac{1}{2} \times 2,667+0,333\right) \\
= & 1079,01 \mathrm{kNm} / \text { meter of wall }
\end{aligned}
$$

Persamaan Slope Deflection untuk setiap member:

Bentang AB 


$$
\begin{aligned}
\mathrm{M}_{\mathrm{AB}} & =\frac{2 \mathrm{EI}}{\mathrm{L}}\left(2 \theta_{\mathrm{A}}+\theta_{\mathrm{B}}\right) \pm \mathrm{FEM} \\
& =\frac{2 \mathrm{EI}}{3}\left(2 \theta_{\mathrm{A}}+\theta_{\mathrm{B}}\right)+\left(-\frac{1}{12} \times 71,934 \times 3^{2}\right)+\left(-\frac{1}{30} \times(125,8876-71,934) \times 3^{2}\right) \\
& =\frac{2 \mathrm{EI}}{3}\left(2 \theta_{\mathrm{A}}+\theta_{\mathrm{B}}\right)-70,1366 \\
\mathrm{M}_{\mathrm{BA}} & =\frac{2 \mathrm{EI}}{\mathrm{L}}\left(\theta_{\mathrm{A}}+2 \theta_{\mathrm{B}}\right) \pm \mathrm{FEM} \\
& =\frac{2 \mathrm{EI}}{3}\left(\theta_{\mathrm{A}}+2 \theta_{\mathrm{B}}\right)+\left(\frac{1}{12} \times 71,934 \times 3^{2}\right)+\left(\frac{1}{20} \times(125,8876-71,934) \times 3^{2}\right) \\
& =\frac{2 \mathrm{EI}}{3}\left(\theta_{\mathrm{A}}+2 \theta_{\mathrm{B}}\right)+78,2296
\end{aligned}
$$

Bentang BC

$$
\begin{aligned}
\mathrm{M}_{\mathrm{BC}} & =\frac{2 \mathrm{EI}}{\mathrm{L}}\left(2 \theta_{\mathrm{B}}+\theta_{\mathrm{C}}\right) \pm \mathrm{FEM} \\
& =\frac{2 \mathrm{EI}}{3}\left(2 \theta_{\mathrm{B}}+\theta_{\mathrm{C}}\right)+\left(-\frac{1}{12} \times 125,8394 \times 3^{2}\right)+\left(-\frac{1}{30} \times(179,8394-125,8876) \times 3^{2}\right) \\
& =\frac{2 \mathrm{EI}}{3}\left(2 \theta_{\mathrm{B}}+\theta_{\mathrm{C}}\right)-110,6 \\
\mathrm{M}_{\mathrm{CB}} & =\frac{2 \mathrm{EI}}{\mathrm{L}}\left(\theta_{\mathrm{B}}+2 \theta_{\mathrm{C}}\right) \pm \mathrm{FEM} \\
& =\frac{2 \mathrm{EI}}{3}\left(\theta_{\mathrm{B}}+2 \theta_{\mathrm{C}}\right)+\left(\frac{1}{12} \times 125,8394 \times 3^{2}\right)+\left(\frac{1}{20} \times(179,8394-125,8876) \times 3^{2}\right) \\
& =\frac{2 \mathrm{EI}}{3}\left(\theta_{\mathrm{B}}+2 \theta_{\mathrm{C}}\right)+118,694
\end{aligned}
$$

Bentang CD

$$
\begin{aligned}
\mathrm{M}_{\mathrm{CD}} & =\frac{2 \mathrm{EI}}{\mathrm{L}}\left(2 \theta_{\mathrm{C}}+\theta_{\mathrm{D}}\right) \pm \mathrm{FEM} \\
& =\frac{2 \mathrm{EI}}{3}\left(2 \theta_{\mathrm{C}}+\theta_{\mathrm{D}}\right)+\left(-\frac{1}{12} \times 179,8394 \times 3^{2}\right)+\left(-\frac{1}{30} \times(233,786-179,8394) \times 3^{2}\right) \\
& =\frac{2 \mathrm{EI}}{3}\left(2 \theta_{\mathrm{C}}+\theta_{\mathrm{D}}\right)-151,063 \\
\mathrm{M}_{\mathrm{DC}} & =\frac{2 \mathrm{EI}}{\mathrm{L}}\left(\theta_{\mathrm{C}}+2 \theta_{\mathrm{D}}\right) \pm \mathrm{FEM} \\
& =\frac{2 \mathrm{EI}}{3}\left(\theta_{\mathrm{C}}+2 \theta_{\mathrm{D}}\right)+\left(\frac{1}{12} \times 179,8394 \times 3^{2}\right)+\left(\frac{1}{20} \times(233,786-179,8394) \times 3^{2}\right) \\
& =\frac{2 \mathrm{EI}}{3}\left(\theta_{\mathrm{C}}+2 \theta_{\mathrm{D}}\right)+159,1556
\end{aligned}
$$

Dengan menggunakan metode boundary condition didapat nilai momen sebagai berikut:

$$
\begin{aligned}
\mathrm{M}_{\mathrm{AB}} & =\frac{2 \mathrm{EI}}{3}(2 \times-141,5188+100,507)-70,136 \\
& =-191,824 \mathrm{kNm} / \text { meter of wall } \\
\mathrm{M}_{\mathrm{BA}} & =\frac{2 \mathrm{EI}}{3}(-141,5188+2 \times 100,507)+78,2296 \\
& =117,893 \mathrm{kNm} / \text { meter of } \text { wall }
\end{aligned}
$$




$$
\begin{aligned}
\mathrm{M}_{\mathrm{BC}} & =\frac{2 \mathrm{EI}}{3}(2 \times 100,507-211,955)-110,6 \\
& =-117,893 \mathrm{kNm} / \text { meter of wall } \\
\mathrm{M}_{\mathrm{CB}} & =\frac{2 \mathrm{EI}}{3}(100,507-2 \times 211,955)+118,694 \\
& =-96,908 \mathrm{kNm} / \text { meter of wall } \\
\mathrm{M}_{\mathrm{CD}} & =\frac{2 \mathrm{EI}}{3}(2 \times-211,955+795,868)-151,063 \\
& =96,908 \mathrm{kNm} / \text { meter of } \text { wall } \\
\mathrm{M}_{\mathrm{DC}} & =\frac{2 \mathrm{EI}}{3}(-211,955+2 \times 795,868)+159,1556 \\
& =1079,01 \mathrm{kNm} / \text { meter of wall }
\end{aligned}
$$

Mencari reaksi vertikal pada tiap strut:

$\mathrm{A}_{\text {kiri }}=\frac{1}{2} \times 4 \times 71,934=143,868 \mathrm{kN} / \mathrm{m}$

$A_{\text {kanan }}=-\left(\frac{-191,824+117,893}{3}\right)+\left(\frac{71,934 \times 3}{2}\right)+\frac{1}{3}\left(\frac{1}{2} \times 3 \times(125,8876-71,934)\right)=159,5212 \mathrm{kN} / \mathrm{m}$

A $=A_{\text {kiri }}+A_{\text {kanan }}=143,868+159,5212=303,3892 \mathrm{kN} / \mathrm{m}$

$\mathrm{B}_{\text {kiri }}=-\left(\frac{-191,824+117,893}{3}\right)+\left(\frac{71,934 \times 3}{2}\right)+\frac{2}{3}\left(\frac{1}{2} \times 3 \times(125,8876-71,934)\right)=137,2109 \mathrm{kN} / \mathrm{m}$

$\mathrm{B}_{\text {kanan }}=-\left(\frac{-117,893-96,908}{3}\right)+\left(\frac{125,8876 \times 3}{2}\right)+\frac{1}{3}\left(\frac{1}{2} \times 3 \times(179,8394-125,8876)\right)=287,4076 \mathrm{kN} / \mathrm{m}$

B $=B_{\text {kiri }}+B_{\text {kanan }}=137,2109+287,4076=424,6185 \mathrm{kN} / \mathrm{m}$

$$
\begin{aligned}
& C_{\text {kiri }}=\left(\frac{-117,893-96,908}{3}\right)+\left(\frac{125,8876 \times 3}{2}\right)+\frac{2}{3}\left(\frac{1}{2} \times 3 \times(179,8394-125,8876)\right)=171,1829 \mathrm{kN} / \mathrm{m} \\
& C_{\text {kanan }}=-\left(\frac{96,908+1079,01}{3}\right)+\left(\frac{179,8394 \times 3}{2}\right)+\frac{1}{3}\left(\frac{1}{2} \times 3 \times(233,786-179,8394)\right)=-95,2403 \mathrm{kN} / \mathrm{m} \\
& \mathrm{C} \quad=C_{\text {kiri }}+C_{\text {kanan }}=171,1829-95,2403=75,9426 \mathrm{kN} / \mathrm{m} \\
& D_{\text {kiri }} \quad=\left(\frac{96,908+1079,01}{3}\right)+\left(\frac{179,8394 \times 3}{2}\right)+\frac{2}{3}\left(\frac{1}{2} \times 3 \times(233,786-179,8394)\right)=715,6784 \mathrm{kN} / \mathrm{m} \\
& D_{\text {kanan }}=(239,78 \times 2,667)+(233,786 \times 0,333)+\left(\frac{1}{2} \times 0,333 \times(239,78-233,786)\right)=718,343 \mathrm{kN} / \mathrm{m} \\
& D \quad=D_{\text {kiri }}+D_{\text {kanan }}=715,6784-718,343=1434,0214 \mathrm{kN} / \mathrm{m}
\end{aligned}
$$

Beban strut pada level yang ditunjukkan oleh subskrip:

Horizontal spacing, $s$-wall $=3 \mathrm{~m}$

$$
\begin{aligned}
& P_{A}=A \times s=303,3892 \times 3=910,1676 \mathrm{kN} \\
& P_{B}=B \times s=424,6185 \times 3=1273,8555 \mathrm{kN} \\
& P_{C}=C \times s=75,9426 \times 3=227,8278 \mathrm{kN} \\
& P_{D}=D \times s=1434,0214 \times 3=4302,0642 \mathrm{kN}
\end{aligned}
$$


Wales pada level strut A memikul beban 910,1676 kN dari strut A. Beban ini didistribusikan sepanjang $3 \mathrm{~m}$, sehingga:

Beban mati merata $=910,1676 / 3=303,3892 \mathrm{kN} / \mathrm{m}$

M pada Wales $\mathrm{A}=\frac{2}{3} \times \frac{1}{10} \times 303,3892 \times 3^{2}=182,0335 \mathrm{kNm}$

Wales pada level strut B memikul beban 1273,8555 kN dari strut B. Beban ini didistribusikan sepanjang $3 \mathrm{~m}$, sehingga:

$$
\begin{aligned}
& \text { Beban mati merata }=1273,8555 / 3=424,6185 \mathrm{kN} / \mathrm{m} \\
& \text { M pada Wales B }=\frac{2}{3} \times \frac{1}{10} \times 424,6185 \times 3^{2}=254,7711 \mathrm{kNm}
\end{aligned}
$$

Wales pada level strut $\mathrm{C}$ memikul beban 227,8278 kN dari strut C. Beban ini didistribusikan sepanjang $3 \mathrm{~m}$, sehingga:

$$
\begin{aligned}
& \text { Beban mati merata }=227,8278 / 3=75,9426 \mathrm{kN} / \mathrm{m} \\
& \text { M pada Wales } \mathrm{C}=\frac{2}{3} \times \frac{1}{10} \times 75,9426 \times 3^{2}=45,5656 \mathrm{kNm}
\end{aligned}
$$

Wales pada level strut D memikul beban 4302,0642 kN dari strut D. Beban ini didistribusikan sepanjang $3 \mathrm{~m}$, sehingga:

$$
\begin{aligned}
& \text { Beban mati merata }=4302,0642 / 3=1434,0214 \mathrm{kN} / \mathrm{m} \\
& \text { M pada Wales D }=\frac{2}{3} \times \frac{1}{10} \times 1434,0214 \times 3^{2}=860,4128 \mathrm{kNm}
\end{aligned}
$$

\section{Perhitungan safety factor pada bottom heave}

Analisa perhitungan analisis ini didasari oleh teori Terzaghi (1943). Penelitian ini mencari faktor keamanan untuk braced-cut pada galian dalam.

$$
\mathrm{FS}=\frac{5.14 \mathrm{c}_{\mathrm{av}}\left(1+\frac{0,2 \mathrm{~B}^{\prime \prime}}{\mathrm{L}}\right)+\frac{\mathrm{c}_{\mathrm{av}} \mathrm{H}}{\mathrm{B}^{\prime}}}{\gamma_{\mathrm{a}} \mathrm{H}+\mathrm{Q}}
$$

$\mathrm{T}=24 \mathrm{~m}$

$\frac{\mathrm{B}}{\sqrt{2}}=\frac{12}{\sqrt{2}}=8,4853 \mathrm{~m}$

Maka,

$\mathrm{T}>\frac{\mathrm{B}}{\sqrt{2}}$

Didapat,

$\mathrm{B}^{\prime}=\frac{\mathrm{B}}{\sqrt{2}}=\frac{12}{\sqrt{2}}=8,4853 \mathrm{~m}$

$\mathrm{B}^{\prime \prime}=\sqrt{2} \times \mathrm{B}^{\prime}=\sqrt{2} \times 8,4853=12 \mathrm{~m}$

$\mathrm{FS}=\frac{5,14(23,28)\left(1+\frac{0,2(12)}{32}\right)+\frac{(23,28)(16)}{8,4853}}{(8,3325)(16)+0}$

$=1,2941>1,2$

Stabilitas galian pada bottom heave dinyatakan aman karena FS $>$ FK yaitu 1,2. 


\section{KESIMPULAN DAN SARAN}

\section{Kesimpulan}

Dari hasil penelitian yang dilakukan, diperoleh kesimpulan berupa:

1. Berdasarkan hasil pengolahan data, didapati bahwa potensi dan tekanan yang diberikan oleh lapisan pasir jauh lebih besar $(373,5683 \mathrm{kN})$ yaitu pada lapisan 6 pada tanah pasif dengan kedalaman 30-36,5 m.

2. Beban yang ditanggung pada setiap strut berbeda tergantung dengan tegangan tanah yang didistribusikan pada lapisan tersebut. Selain itu, jarak horizontal spacing antar strut juga mempengaruhi beban yang ditanggung, semakin besar jaraknya maka akan semakin besar juga beban yang ditanggung. Dari perhitungan beban strut ini didapat beban masing-masing strut sebagai berikut.

Strut A $=910,1676 \mathrm{Kn}$

Strut $\mathrm{B}=1273,855 \mathrm{kN}$

Strut $\mathrm{C}=227,8278 \mathrm{kN}$

Strut $\mathrm{D}=4302,0642 \mathrm{kN}$

3. Beban yang dipikul oleh masing-masing strut akan didistribuskan terhadap wales tiap strut berupa momen. Beban tersebut dianggap beban merata dengan horizontal spacing sebagai panjangnya. Dari perhitungan momen yang didstribusikan terhadap wales masing-masing sebagai berikut:

Wales $\mathrm{A}=182,0335 \mathrm{kN}$

Wales $\mathrm{B}=254,7711 \mathrm{kN}$

Wales $\mathrm{C}=45,5656 \mathrm{kN}$

Wales $\mathrm{D}=860,4128 \mathrm{kN}$

4. Safety factor pada bottom heave dengan tebal $24 \mathrm{~m}$ dinyatakan aman karena diatas batas faktor keamanan yaitu 1,2 .

\section{Saran}

1. Penanganan terhadap penurunan dari $D$-wall dapat dilakukan dengan beberapa cara, seperti memperbesar dimensi dinding, memperdalam dinding atau dinding sampai menyentuh tanah keras, menggunakan support system yang salah satunya adalah dengan strut-beam.

2. Dalam perencanaan suatu proyek, sebaiknya dilakukan pengecekan tanah juga di luar dari tanah proyek, karena setiap titik bisa memiliki lapisan tanah yang berbeda dan dapat mempengaruhi besar tegangan yang diterima oleh $D$-wall.

\section{DAFTAR PUSTAKA}

Hardiyatmo, H. C. Teknik Pondasi 2. Yogyakarta: PT Gramedia Pustaka Utama,1996.

Hardiyatmo, H. C. Analisis dan Perancangan Fondasi I. Vol. Edisi Ketiga. Yogyakarta: Gajah Mada Universitas Press, 2011.

M.Das, B. Principles of Geotechnical Engineering. 5th. 2002.

M.Das, B. Principles of Geotechnical Engineering. $8^{\text {th }} .2002$.

SNI Geoteknik 8460:2017 Persyaratan Perancangan Geoteknik. Jakarta: Badan Standardisasi Nasional, 2017.

$\mathrm{Wu}$, Minger. "Analytical method for the lateral buckling of the struts in beam string structures." Engineering Structures 30 (2008): 2301-2310.

Zhang, Wengang. "Estimation of strut forces for braced excavation in granular soils from numerical analysis and case histories." Computers and Geotechnics October 2018 (2019): 286-295. 
